University of Wollongong

Research Online

Faculty of Business - Papers (Archive)

Faculty of Business and Law

$1-1-2015$

Measuring productivity change in higher education: an application of HicksMoorsteen total factor productivity index to Malaysian public universities

Amir Arjomandi

University of Wollongong, amira@uow.edu.au

Mad Ithnin Salleh

Sultan Idris Education University, mis159@uowmail.edu.au

Abbas Mohammadzadeh

University of Wollongong, am989@uowmail.edu.au

Follow this and additional works at: https://ro.uow.edu.au/buspapers

Part of the Business Commons

Research Online is the open access institutional repository for the University of Wollongong. For further information contact the UOW Library: research-pubs@uow.edu.au 


\title{
Measuring productivity change in higher education: an application of Hicks- Moorsteen total factor productivity index to Malaysian public universities
}

\author{
Abstract \\ This paper offers an in-depth analysis of efficiency and productivity changes using the Hicks-Moorsteen \\ total factor productivity index, in the context of higher education institutions. Unlike the Malmquist \\ method, this approach makes no assumptions about firms' returns to scale conditions. We assume that \\ the production technology exhibits variable returns to scale, which is more plausible than the constant \\ returns to scale assumption, because universities usually operate at suboptimal scales. Three major \\ groupings of Malaysian public universities are used in our case study: research, comprehensive, and \\ focused universities. The results show that technical efficiency has improved after the 2007 National \\ Higher Education Strategic Plan within all the three university groupings.
}

\section{Keywords}

higher, education, measuring, application, productivity, hicks, moorsteen, total, factor, index, malaysian, public, universities, change

\section{Disciplines \\ Business}

\section{Publication Details}

Arjomandi, A., Salleh, M. Ithnin. \& Mohammadzadeh, A. (2015). Measuring productivity change in higher education: an application of Hicks-Moorsteen total factor productivity index to Malaysian public universities. Journal of the Asia Pacific Economy, 20 (4), 630-643. 


\title{
Measuring Productivity Change in Higher Education: An Application of Hicks-Moorsteen Total Factor Productivity Index to Malaysian Public Universities
}

\author{
Amir Arjomandi ${ }^{\text {a }}$, Mad Ithnin Salleh ${ }^{\text {, }}$, Abbas Mohammadzadeh ${ }^{\text {a }}$ \\ a School of Accounting, Economics and Finance, University of Wollongong, Northfields Avenue, \\ Wollongong, NSW 2522, Australia \\ ${ }^{\mathrm{b}}$ Faculty of Management and Economics, Universiti Pendidikan Sultan Idris, 35900 Tanjong Malim, \\ Malaysia
}

\begin{abstract}
This paper offers an in-depth analysis of efficiency and productivity changes using the Hicks-Moorsteen total factor productivity (TFP) index, in the context of higher education institutions. Unlike the Malmquist method, this approach makes no assumptions about firms’ returns-to-scale conditions. We assume that the production technology exhibits variable returns to scale, which is more plausible than the constant returns to scale assumption, because universities usually operate at suboptimal scales. Three major groupings of Malaysian public universities are used in our case study: research, comprehensive, and focused universities. The results show that technical efficiency has improved after the 2007 National Higher Education Strategic Plan within all the three university groupings.
\end{abstract}

Keywords: total factor productivity, higher education institutions, efficiency, Malaysia

JEL classification codes: C14, D24, H52, I21.

\section{Introduction}

The Malmquist productivity index is considered the most appropriate tool for measuring changes in efficiency and productivity of firms. Johnes (2008), Worthington, and Lee (2008), Agasisti and Johnes (2009), and Bradley et al. (2010) are among the most recent studies to have applied this useful tool. Despite its evident popularity, however, there has also been 
extensive discussion of the arguments for and against using constant returns to scale (CRS) to estimate Malmquist indices. Grifell-Tatje and Lovell (1995) and O’Donnell (2012a) argue that with non-constant returns to scale, the Malmquist index is not able to measure productivity change precisely. This bias is systemic, and depends on the magnitude of scale economies (Coelli and Rao 2005). Ray and Desli (1997) and Wheelock and Wilson (1999) argue that when a firm's location (from one period to another) remains unchanged, and the changes in scale efficiency are only related to a shift in the variable returns to scale (VRS) estimate of technology, there will be no resulting technical change under CRS. Hence, the resulting CRS estimate of technology may be statistically inconsistent. Consequently, Wheelock and Wilson (1999) state that the popular decomposition of the Malmquist index conducted by Färe et al. (1994) is also problematic.

In order to avoid the above problem, O’Donnell (2012a) proposes a new approach to decompose the "multiplicatively complete" TFP indices (those that can be presented in terms of aggregate inputs and aggregate outputs) into technical change and different measures of efficiency change. O’Donnell does this without making any assumptions about the optimizing behaviour of firms, their market structure, or returns to scale for a multiple-input, multipleoutput case. O’Donnell (2012a) also proves that the group of complete TFP indices include the Fisher, Konus, Törnqvist, and Hicks-Moorsteen indices, but not the Malmquist index.

In the context of the higher education system, because universities are not operating at optimal scale and they face imperfect competition, the new decomposition of the HicksMoorsteen TFP index can be utilized, allowing us to analyze changes in the productivity of firms under the VRS assumption. Although extensive research has been carried out on the productivity of higher education institutions, no single study has investigated TFP of universities under the VRS assumption. Another advantage of the use of the Hicks- 
Moorsteen TFP index is that it reduces the possibility of producing infeasible results (Epure et al. 2011). ${ }^{1}$ In addition, in their recent comprehensive comparison of the Malmquist index and Hicks-Moorsteen index, Kerstens and Van de Woestyne (2014, p.756) clearly state: “As to the question whether the Malmquist and Hicks-Moorsteen indices are empirically indistinguishable or not, the differences between both primal productivity indices turn out to be significantly different for all flexible returns to scale technology specifications.” Kerstens and Van de Woestyne (2014, p.756) recommend that "if one wants to be on the safe side, then one conclusion is that in case the interest centers on TFP measurement it is probably wise to immediately opt for the Hicks-Moorsteen index.” Based on the above evidence, this study uses the Hick-Moorsteen index to analyze the performance of universities. To the best of our knowledge, this study is the first employing this index in the area of higher education.

The Malaysian public higher education sector is used as a case study mainly because in the last decade the Malaysian government has emphasized productivity improvement in the public higher education sector, in recognition of its role as an engine for promoting the development of quality human capital. Overall, Malaysia is keen to be recognized as a major hub for higher education in the region and has launched policies for supporting the internationalization and improving the teaching and learning quality, together with enhancements of research and competition in the sector. This sector, therefore, has undergone some fundamental changes, which have led to its rapid expansion over the last decade. In particular, the implementation of the NHESP (National Higher Education Strategic Plan, "the plan”) in 2007 was the most important policy change in this area. Kaur and Sirat (2010) argue that this plan is Malaysia's key policy initiative in revolutionizing and transforming higher education. As part of this plan, the government raised the share of research and development in gross domestic product (GDP) from $1.5 \%$ to $4.9 \%$, with public universities being the 
recipients of these national research and development funds (Malaysian Ministry of Higher Education 2007). Despite the large allocation of funds into the sector, however, there has been no empirical study of the effect of the plan on the performance of public universities. This study, therefore, uses the Hicks-Moorsteen TFP index under VRS and a four-year panel dataset (2006 to 2009) to evaluate productivity changes of Malaysian public universities.

The remainder of this paper is structured as follows. Section 2 presents a brief literature review of the related studies on the efficiency and productivity changes in the area of higher education. Section 3 discusses the Hicks-Moorsteen TFP index and its decompositions. Section 4 describes the data employed and the input and output classifications. Section 5 presents our empirical results, followed by some concluding remarks in Section 6 .

\section{Literature review}

There has been a rapid expansion during the last few decades in the use of nonparametric approaches in measuring the efficiency and productivity changes of higher education institutions. A large number of these studies have been undertaken in developed countries (e.g. Athanassapoulos and Shale 1997; Abbott and Doucouliagos 2003; Emrouznejad and Thanassoulis 2005; Johnes 2006). Only a few of the higher education studies pertain to developing countries. For instance, $\mathrm{Ng}$ and $\mathrm{Li}$ (2000) examine the efficiency of 84 key Chinese higher education institutions in the post-reform period (1993-1995) using data envelopment analysis (DEA). Focusing on the research performance of these universities, they found that their performance has, on average, improved over time. In another study of developing countries, Cokgezen (2009) investigates the technical efficiency of faculties of economics in Turkey in 2004. The results indicate an overall low level of efficiency with some variations across the faculties. 
Focusing mainly on efficiency estimates may lead to an incomplete view of the performance of universities over time. Changes in distance function values may occur over time due to two reasons: 1) efficiency changes (the movement of universities within the input-output space); or 2) technological changes (the changes of the boundary of the production set). The decomposition of the TFP indices (such as the Malmquist index) makes it possible to distinguish between changes in efficiency, productivity, and technological changes. However, only a small, but growing, number of studies have so far attempted to use the Malmquist index for this purpose, among them, Flegg et al. (2004), Carrington et al. (2005), Johnes (2008), Worthington and Lee (2008), Agasisti and Johnes (2009), and Bradley et al. (2010). Most of these studies have found productivity progress in different sectors, but this is mainly attributed to changes in technology and/or efficiency. For example, Flegg et al. (2004) examine changes in the productivity of 45 British universities during the period 19801993 and show that positive variations in productivity were due to technological change, rather than efficiency change. In a study of 35 Australian universities, Worthington and Lee (2008) also identify similar results in productivity growth. Agasisti and Johnes (2009) provide cross-country efficiency and productivity comparisons of English and Italian universities over a four-year period (2002-2005), attributing the overall productivity progress in each country to technological improvements and efficiency growth, respectively. Bradley et al. (2010) investigate 200 further education providers in UK during the period 1999-2003. Their results show that the sector's productivity growth stems from both technical efficiency and technological changes.

Despite the growing literature associated with the application of the conventional Malmquist index, little is documented about the application of the Hicks-Moorsteen index. Some of the main applications of this index are O’Donnell (2010a; 2012a; 2012b) in the 
context of the agricultural sector, Simões and Marques (2012) in the waste sector and Epure et al. (2011), and Arjomandi (2012; 2014) in the banking sector.

\section{Hicks-Moorsteen TFP index and its components}

Considering a firm with multiple inputs and outputs, according to Jorgenson and Griliches (1967) and Good et al. (1997), TFP can be defined as $T F P_{n t}=Y_{n t} / X_{n t}$, where $Y_{n t}$ and $X_{n t}$ are, respectively, the aggregate output and aggregate input of the $n^{\text {th }}$ firm in period $t$. Based on this definition, we may specify TFP changes as being the ratio of an output quantity index to an input quantity index. O’Donnell (2012a) refers to such index numbers as multiplicatively complete. Among the multiplicatively complete indices, the Hicks-Moorsteen TFP index is the only one that can be estimated without requiring price data. This index is in fact a ratio of Malmquist output and input quantity indices, which is based on the works of Hicks (1961) and Moorsteen (1961):

$$
\operatorname{TFP}_{H M}^{t, t+1}=\left(\frac{D_{o}^{t+1}\left(x^{t+1}, y^{t+1}\right) D_{o}^{t}\left(x^{t}, y^{t+1}\right)}{D_{o}^{t+1}\left(x^{t+1}, y^{t}\right) D_{o}^{t}\left(x^{t}, y^{t}\right)} \frac{D_{I}^{t+1}\left(x^{t}, y^{t+1}\right) D_{I}^{t}\left(x^{t}, y^{t}\right)}{D_{I}^{t+1}\left(x^{t+1}, y^{t+1}\right) D_{I}^{t}\left(x^{t+1}, y^{t}\right)}\right)^{1 / 2}
$$

In Equation 1, $D_{o}(x, y)$ and $D_{I}(x, y)$ are output and input distance functions, respectively, defined as $D_{o}^{T}(x, y)=\min \left\{\delta>0:(x, y / \delta) \in P^{T}\right\}$, and $D_{I}^{T}(x, y)=\max \left\{\rho>0:(x / \rho, y) \in P^{T}\right\}$, where $P^{T}$ is the period $T$ production possibilities set. ${ }^{2}$ These distance functions can be calculated using Data Envelopment Analysis (DEA) models developed by O’Donnell (2012a). DEA does not necessitate any restrictive assumptions regarding the functional form and efficiency distribution. It must be noted, however, that DEA has its own limitations as it makes no allowance for statistical noise, and hence one should be cautious in the interpretation of the results. Because of this statistical shortcoming, any possible measurement errors in the data could make the estimated efficiency and TFP components to some extent biased. One way to 
quantify the magnitude of the possible errors is to estimate the technology using an econometric methodology, such as stochastic frontier analysis, which allows for statistical errors. However, the use of such an approach is not possible in this paper as there are only 17 observations per year, one for each university. Notwithstanding these possible shortcomings, we perceive that the potential risks associated with using a DEA-based Hicks-Moorsteen TFP index are outweighed by the potential benefits and valuable insights that this advanced technique can provide us.

The output-oriented decomposition of a multiplicatively complete TFP index for firm $n$ in period $t$ can be rewritten as:

$T F P_{n t}=T F P_{t}^{*} \times\left(O T E_{n t} \times O M E_{n t} \times O S E_{n t}\right)$

Where $\operatorname{TFP}_{t}^{*}$ is the maximum TFP possible using any technically feasible inputs and outputs; $O T E_{n t}$ (output-oriented technical efficiency) measures the difference between observed TFP and the maximum TFP that is possible while holding the input-output mix and input level fixed; $O M E_{n t}$ (output-oriented mix efficiency) measures the change in productivity when restrictions on the input and output mix of the firm are relaxed; and $O S E_{n t}$ (output-oriented scale efficiency) measures the difference between TFP at a technically and mix efficient point and TFP at the point of optimum productivity.

The interpretation of efficiency measures is straightforward. A technical efficiency estimate of unity indicates that the firm lies on the boundary of the production set, and as such, the corresponding firm is said to be relatively efficient. On the other hand, an estimated value below unity shows that the firm is positioned under the frontier and is relatively 
inefficient. A firm with technical efficiency equal to unity, but with scale and mix efficiencies less than unity, is still on the frontier, but at a relatively unproductive point.

A similar equation to Equation 2 can be formulated for any other firm like $m$ in period $s$. Accordingly, the index number that compares the TFP of firm $n$ in period $t$ with the TFP of firm $m$ in period $s$ can be written as:

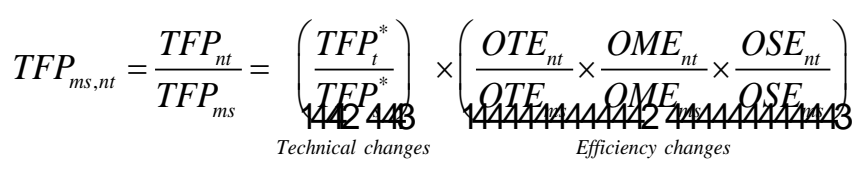

The term included in the first parentheses on the right-hand side of this equation represents technical changes, measuring the difference between the maximum TFP possible using any technology feasible at times $t$ and $s$. Hence, the sector experiences technical improvement or decline, depending on whether $T F P_{t}^{*} / T F P_{s}^{*}$ is greater or less than 1 . Unlike in the decomposition of the Malmquist index of Färe et al. (1994), the technical change in Equation 3 contains a mixed effect, and characteristically varies from firm to firm. The three other ratios on the extreme right-hand side of Equation 3 are various components of technicalefficiency changes and are referred to as measures of technical-efficiency change, mixefficiency change, and scale-efficiency change. We used the DPIN software written by O’Donnell (2010b) to estimate different measures of efficiency and TFP components.

\section{The data}

This study utilizes a four-year panel dataset (2006-2009) for analysing the performance of 17 Malaysian public universities in the years before and after the implementation of the NHESP. The sector consists of 20 public universities, which are categorized into three different subgroups: research universities, comprehensive universities, and focused universities. ${ }^{3}$ The only public universities not included here are Universiti Malaysia Kelantan, Universiti 
Pertahanan Nasional Malaysia, and Universiti Sultan Zainal Abidin, as their data were unavailable. The 17 universities are divided into three groups: 1) five research universities ${ }^{4}$; 2) four comprehensive universities ${ }^{5}$; and 3) eight focused universities. ${ }^{6}$ The data were extracted from the Higher Education Statistical Yearbooks of the Malaysian Ministry of Higher Education (2009) and the Elsevier Scopus database.

As the Hicks-Moorsteen approach is a distance-based index, non-parametric DEA models are employed to estimate the institutions' efficiency and productivity changes. An important advantage of the DEA approach is that it works well with a small sample size. The small sample of 17 universities in this paper is not sufficient for parametric (econometric) techniques. Several studies in the literature also work with small sample sizes (e.g., Tomkins and Green 1988; Sinuany-Stern et al. 1994; Haksever and Muragishi 1998; Korhonen et al. 2001; Emrouznejad and Thanassoulis 2005).

The important issue in the use of the DEA approach relates to the correct selection of inputs and outputs. However, there is no consensus in the literature as to how to specify the inputs and outputs (Avkiran 2001). According to Lindsay (1982, p. 176), some characteristics of the higher education institutions such as "lack of profit motivation, goal diversity and uncertainty, diffuse decision making and poorly understood production technology” differentiate this sector from other industries and complicate the specification of the variables. Carrington et al. (2005) also state that it is difficult to accurately define the university inputs and outputs, because they are diverse and multifaceted.

The choice of inputs and outputs in this study is based on the production approach studies by Athanassapoulos and Shale (1997) and Glass et al. (2006), and Worthington and Lee (2008). These studies assume that universities combine labour and non-labour factors of 
production to produce outputs in the form of teaching, research and other educational services.

The four inputs included in our analysis, which are fully described in Table 1 and 2, are as follows: 1) undergraduate enrolments; 2) postgraduate enrolments; 3) the number of full-time equivalent academic staff members; and 4) the allocated government research funding. The student enrolments for undergraduate and postgraduate degrees are important input variables. Both changed significantly after 2006 in most of the universities, with undergraduate enrolment increasing from 223,606 in 2006 to 267,200 in 2009, and postgraduate enrolment increasing from 39,099 in 2006 to 59,137 in 2009. We included total student enrolments, instead of the more commonly used full-time equivalent student loads, due to the unavailability of some data. This difficulty was also experienced by Agasisti and Johnes (2009). Our three outputs are defined as follows: 1) the number of undergraduate qualifications awarded; 2) the number of postgraduate qualifications awarded; and 3) the number of refereed articles as a proxy for research output.

Three observations are noteworthy at this point. First, student inputs are assumed to be homogeneous, because there was no easy way to capture quality. This is consistent with DEA models of previous studies (e.g., Athanassapoulos and Shale 1997; Johnes 2008; Worthington and Lee 2008). Second, some studies have taken into account the quality of undergraduate output by using the number of graduates receiving a first class degree (see Flegg et al. 2004). However, our study has not adopted this approach because of data inaccuracy. Third, we mainly focus on teaching and research as the most important activities of universities. In other words, we have not incorporated a third type of output, community services, because there is no accepted or easy way to evaluate community and consultation services across 
universities (see Ahn, et al. 1989; Carrington et al. 2005; Johnes 2008; Worthington and Lee 2008).

\section{[Tables 1 and 2 about here]}

There are many ways of measuring university research outputs (e.g., Carrington et al. 2005; Glass et al. 2006). Abbott and Doucouliagos (2003) argue that one should consider both quantity and quality of research outputs. As a proxy for research output, several studies have used research income (e.g., Abbott and Doucouliagos 2003; Flegg et al. 2004; Johnes 2008; Worthington and Lee 2008). Malaysian universities do not usually provide consistent reports of their research outputs; different definitions are used and they frequently change over time. Against this backdrop, we employed an alternative proxy for research output data, known as the pure bibliometric approach, using the number of published research papers in refereed journals.

The bibliometric approach possesses a considerable advantage over other alternatives such as the peer-review approach. ${ }^{7}$ For instance, it costs less, is non-invasive, easy to implement and ensures rapid updates. Application of the bibliometric approach is usually based on data extracted from the Thomson Reuters Web of Science (WoS), a practice common to previous studies (see Abramo and D’Angelo 2011; Abramo et al. 2011). However, the Scopus database is likely a better choice because it covers more refereed journals and conference proceedings than WoS (Meho and Rogers 2008), and also provides the best coverage in social-science literature (Norris and Openheim 2007). It is noteworthy that the WoS database mainly covers the North American, Western European and English-language outlets (Meho and Yang 2007). Thus, in the case of the Malaysian higher education institutions, we consider the Scopus database the most appropriate source. 
In the process of counting the number of refereed articles by each university, we took care to ensure the accuracy of the data. For example, issues of affiliation were treated cautiously when some authors used their faculty as their affiliation rather than their university. Additionally, where co-authors were from the same institution, we gave due consideration to the issue of double counting. To overcome this problem, we gave weights to each university based on the total number of authors. For instance, for an article with three authors (two from university A and one from university B), university A was weighted 2/3 and university B was weighted $1 / 3$. If we had have given equal weights to all three universities, the results would have been overestimated.

\section{Empirical results}

Table 3 presents the estimated means of output-oriented technical efficiency (OTE), outputoriented scale efficiency (OSE), and output-oriented mix efficiency (OME) in four different groups of the universities (i.e., research universities, comprehensive universities, focused universities, and the sector as a whole) for the period 2006-2009. Columns 3 to 5 of Table 3 list the means of OTE, OSE and OME for each year, respectively. This table reveals that the technical efficiency and mix efficiency for the sector as a whole decreased between 2006 and 2007 and then rose notably after 2007. More specifically, OTE increased from 0.9561 in 2007 to 0.9993 in 2008, and OME improved largely from 0.8755 in 2007 to 0.9709 in 2008 . Although the mean values for OTE and OME fell in 2009, the value of these measurements were still higher than those observed prior to 2008, suggesting an overall improvement in the sector after the implementation of policy reforms embedded in the 2007 NHESP. We may argue that the positive changes occurring after 2007 were mainly related to the implementation of the NHESP, which helped the public universities to enhance their staff and resource usage efficiency. 


\section{[Table 3 about here]}

In terms of scale efficiency, the results are quite mixed. For instance, the focused universities subgroup show low levels of scale efficiency in 2006 and 2008 and high scale efficiency levels in 2007 and 2009. This may be due to the fact that most of these universities had been upgraded from colleges to universities, and were not operating on an optimal scale. However, public universities do not necessarily need to be scale efficient. For example, one possible reason could be that these universities have to follow government prescribed policies, such as opening additional branches in rural areas, as well as encouraging employment of additional staff in such areas.

Table 4 presents the universities' total factor productivity changes $(\triangle T F P)$ and its components, technical change ( $\Delta$ Tech) and efficiency change ( $\Delta$ Eff), for all of the four groups between 2006 and 2009. The table also presents various components of the $\Delta E f f$ : changes in pure technical efficiency $(\triangle O T E)$, residual scale efficiency $(\triangle R O S E)$, and mix efficiency $(\triangle O M E)$. The interpretation of the results is straightforward. An estimated value greater (less) than unity indicates an improvement (worsening) in the corresponding measure.

\section{[Table 4 about here]}

A cursory look at Table 4 shows that mix efficiency change $(\triangle O M E)$ is the major component of the changes in efficiency ( $\triangle E f f)$ in all periods. For instance, in 2006-2007, the sector experienced a significant deterioration in $\Delta E f f$ by $-56.83 \%(\Delta E f f=0.4317)$, which was attributable to the $59.4 \%$ negative change of $\triangle O M E(\triangle O M E=0.406)$. However, the sector's efficiency change improved markedly by $302.31 \%(\Delta E f f=4.0231)$ in $2007-2008$ and $45 \%$ $(\Delta E f f=1.452)$ in 2008-2009 because of large mix-efficiency developments of $1.9695 \%$ $(\triangle O M E=2.9695)$ and $0.5323 \%(\triangle O M E=1.5323)$, respectively. This reflects an overall 
improvement in the way the universities' resources were allocated in the post-NHESP era. Table 4 shows that $\triangle O M E$ is also the most important component of the TFP changes in 2007-2008 and 2008-2009. As a result of large mix efficiency changes in these periods, the sector experienced TFP growth of $28.3 \%$ and $62.15 \%$ in 2007-2008 and 2008-2009, respectively.

$\Delta$ Tech (technical changes) was found to be the second most important component of TFP changes. Table 4 reveals that $\Delta$ Tech appears to be the same for each university in all periods, suggesting that all institutions have the same access to the same production possibility set. ${ }^{8}$ As a result, any shifts in the production possibility set resulting from changes in external factors and/or government intervention can affect all universities equally, either in terms of improvement or worsening of the production frontier. Table 4 shows that the sector experienced remarkable growth of $\Delta$ Tech in 2006-2007 $(\Delta T e c h=3.2118)$ and 2008-2009 $(\Delta T e c h=1.1167)$ and a slight negative change in $\Delta$ Tech during 2007-2008 $(\Delta$ Tech $=$ 0.3188). Hence, we may conclude that the sector's $\Delta$ Tech largely improved during 20062009. One possible explanation for this positive achievement can be related to the widespread use of information technology and electronic learning initiatives launched within the Malaysian universities in this period. As highlighted by Johnes (2008), an increased use of technology and e-learning activities can facilitate the accessibility of information for students, and diversify teaching methods and boost administrative efficiency. In addition, Johnes (2008) states that the technological improvements can also strengthen the universities' research capability to undertake further collaborative research.

A general comparison of TFP changes of different subgroups in Table 4 reveals that research and comprehensive universities that were experiencing productivity regress before 2007 show considerable productivity growth after the implementation of the NHESP. Table 4 
also reveals that the focused universities recorded better performance than the other two subgroups in all of the periods. In sum, our results provide convincing evidence that the sector as a whole enjoyed significant productivity progress during the sample period (20062009), particularly over the post-NHESP era (2008-2009).

\section{Conclusions}

This paper uniquely uses an alternative approach to decompose the Hicks-Moorsteen TFP index to examine efficiency and productivity changes in a higher education context. We investigate the efficiency and productivity changes in three groups of the Malaysian public universities (namely, research universities, comprehensive universities, and focused universities) over the period 2006-2009. The study period covers the implementation of the NHESP in 2007 so that a meaningful analysis of productivity and efficiency changes would be feasible. Four different components of productivity changes are estimated: technical changes, changes in pure efficiency, changes in scale efficiency, as well as changes in mix efficiency. Different efficiency measures are also computed.

Based on our findings, the overall sector's mix and technical efficiency levels (outputoriented technical efficiency) decreased in the period 2006-2007, then significantly improved over 2007-2008 and slightly declined during 2008-2009. The overall efficiency improvement of the sector coincided with the implementation of new policies embedded in the NHESP. This plan was aimed at strengthening the principles of good governance in the university delivery system, improving accessibility and equity of resources in the public higher education sector, enhancing the universities' innovation capabilities and the quality of teaching and learning. Thus, we may state that the NHESP has positively affected the efficiency and productivity of various groups of Malaysian universities. As to the slight deterioration of technical efficiency and mix efficiency in 2009, the plan is still progressing, 
and public universities have not completely adapted the proposed structure and support mechanisms. Therefore, some of the positive outcomes of the plan cannot be measured until more data become available in the foreseeable future.

We found the observed TFP improvements were mainly attributable to mix efficiency and technological changes. We consider that such achievements are a result of advancements in information, communication, and technology, as well as the increased use of e-learning facilities in the public higher education sector. This result aligns with previous international higher education productivity studies, which found that technological changes were a significant factor in university productivity growth (see Flegg et al. 2004; Johnes 2008; Worthington and Lee 2008).

We also found that the two groups of universities experiencing productivity regresses before 2007 (i.e., research and comprehensive universities) experienced considerable productivity gains after the introduction of the NHESP. Focused universities had the highest level of productivity growth compared to the other two subgroups in all the periods.

While this study has provided evidence of improvements in the efficiency and productivity of Malaysian higher education universities after the 2007 NHESP, there is an urgent need to consider strategies for the sustainability of such achievement. The second phase of the plan, named “Malaysia’s Global Reach: A New Dimension”, will run from 2011 to 2015 with the aim of ensuring that the higher education sector continues to be globally competitive by fostering greater collaboration between Malaysian institutes of higher learning, reinforcing networking and internationalizing the curriculum. The new phase should further strengthen and consolidate Malaysian higher education institutions to be more competitive and support 
their contributions in the global arena. Future studies may reveal the effects of these additional reforms.

\section{Acknowledgements}

We wish to thank the anonymous referee, whose invaluable inputs and comments considerably improved an earlier version of this article. The usual caveat applies. 


\section{References}

Abbott, M. \& Doucouliagos C. (2003). The efficiency of Australian universities: A data envelopment analysis. Economics of Education Review, 22, 89-97.

Abramo, G., Cicero, T., \& D’Angelo, C. (2011). A field-standardized application of DEA to nationalscale research assessment of universities. Journal of Informetrics, 5, 618-28.

Abramo, G. \& D’Angelo, C. (2011). Evaluating research: From informed peer review to bibliometrics. Scientometrics, 87, 499-514.

Agasisti, T. \& Johnes, J. (2009). Beyond frontiers: Comparing the efficiency of higher education decision-making units across more than one country. Education Economics, 17, 59-79.

Ahn, T., Arnold, V., Charnes, A., \& Cooper, W.W. (1989). DEA and ratio efficiency analysis for public institutions of higher learning in Texas. Research in Governmental and Nonprofit Accounting, 5, 165-85.

Arjomandi, A., Harvie, C. \& Valadkhani, A. (2012). An empirical analysis of Iran's banking performance. Studies in Economics and Finance, 29 (4), 287-300.

Arjomandi, A., Valadkhani, A., \& Harvie, C. (2011). Analysing productivity changes using the bootstrapped Malmquist approach: The case of the Iranian banking industry. Australasian Accounting Business and Finance Journal, 5, 35-56.

Arjomandi, A., Valadkhani, A. \& O’Brien, M. (2014). Analysing banks' intermediation and operational performance using the Hicks-Moorsteen TFP index: The case of Iran. Research in International Business and Finance, 40, 111-25.

Athanassapoulos, A. \& Shale, E. (1997). Assessing the comparative efficiency of higher education. Education Economics, 5, 117-34.

Avkiran, N.K. (2001). Investigating technical and scale efficiencies of Australian universities through data envelopment analysis. Socio-Economic Planning Sciences, 35, 57-80.

Bradley, S., Johnes, J., \& Little, A. (2010). Measurement and determinants of efficiency and productivity in the further education sector in England. Bulletin of Economic Research, 62, 1-30.

Briec, W. \& Kerstens, K. (2004). A Luenberger-Hicks-Moorsteen productivity indicator: its relation to the Hicks-Moorsteen productivity index and the Luenberger productivity indicator. Economic Theory, 23, 925-39.

Briec, W. \& Kerstens, K. (2011). The Hicks-Moorsteen productivity index satisfies the determinateness axiom. Manchester School, 79(4), 765-75.

Briec, W., Kerstens, K. \& Peypoch, N. (2012). Exact relations between four definitions of productivity indices and indicators. Bulletin of Economic Research, 64(2), 265-74.

Carrington, R., Coelli, T., \& Rao, D.S.P. (2005). The performance of Australian universities: Conceptual issues and preliminary results. Economic Papers, 24, 145-63.

Coelli, T.J. \& Rao, D.S.P. (2005). Total factor productivity growth in agriculture: A Malmquist index analysis of 93 countries, 1980-2000. Agricultural Economics, 32, 115-34.

Cokgezen, M. (2009). Technical efficiency of faculties of economics in Turkey. Education Economics, 17, 81-94. 
Emrouznejad, A. \& Thanassoulis, E. (2005). A mathematical model for dynamic efficiency using data envelopment analysis. Applied Mathematics and Computation, 160, 363-78.

Epure, M., Kerstens, K., \& Diego, D. (2011). Technology-based total factor productivity and benchmarking: New proposals and an application. Omega International Journal of Management Science, 39, 608-19.

Färe, R., Grosskopf, S., Norris, M., \& Zhongyang, Z. (1994). Productivity growth, technical progress, and efficiency change in industrialized countries. American Economic Review, 84, 66-83.

Flegg, A.T., Allen, D.O., Field, K., \& Thurlow, T.W. (2004). Measuring the efficiency of British universities: A multi-period data envelopment analysis. Education Economics, 12, 231-49.

Gilbert, R.A. \& Wilson, P.W. (1998). Effect of deregulation in the productivity of Korean banks. Journal of Economics and Business 50, 133-55.

Glass, J.C., McCallion, G., McCillop, D.G., Rasaratnam S., \& Stringer, K.S. (2006). Implications of variant efficiency measures for policy evaluations in UK higher education. Socio-Economic Planning Sciences, 40, 119-42.

Glass, J.C. \& McKillop, D.G. (2000). A post deregulation analysis of the sources of productivity growth in UK building societies. Manchester School, 68, 360-85.

Good, D., Nadiri, M.I., \& Sickles, R. (1997). Index number and factor demand approaches to the estimation of productivity. In H. Pesaran \& P. Schmidt (Eds.), Handbook of Applied Econometrics (14-80). Oxford: Basil Blackwell.

Grifell-Tatjé, E. \& Lovell, C.A.K. (1995). A note on the Malmquist productivity index. Economics Letters 47, 169-75.

Haksever, C. \& Muragishi, Y. (1998). Measuring value in MBA programmes. Education Economics, 6, 11-25.

Hicks, J.R. (1961). Measurement of capital in relation to the measurement of other economic aggregates. In F.A. Lutz \& D.C. Haque (Eds.), Theory of capital (18-31). London: Macmillan.

Johnes, G. (1995). Scale and technical efficiency in the production of economic research. Applied Economics Letters 2, 7-11.

Johnes, J. (2006). Measuring teaching efficiency in higher education: An application of data envelopment analysis to economics graduates from UK universities 1993. European Journal of Operational Research, 174, 443-56.

Johnes, J. (2008). Efficiency and productivity change in the English higher education sector from 1996/97 to 2004/5. Manchester School, 76, 653-74.

Jorgenson, D.W. \& Griliches, Z. (1967). The explanation of productivity change. The Review of Economic Studies, 34, 249-83.

Kaur, S. \& Sirat, M. (2010). Going for global university ranking through the accelerated programme for excellence (APEX) in Malaysia: Full throttle ahead. In S. Kaur, M. Sirat, \& G.T. William (Eds.), Quality Assurance and University Rankings in Higher Education in the Asia Pacific (194217). Pulau Pinang: Universiti Sains Malaysia Press.

Kerstens, K. \& Van de Woestyne, I. (2014). Comparing Malmquist and Hicks-Moorsteen productivity indices: Exploring the impact of unbalanced vs. balanced panel data. European Journal of Operational Research, 233(3), 749-58. 
Korhonen, P., Tainio, R., \& Wallenius, J. (2001). Value efficiency analysis of academic research. European Journal of Operational Research, 130, 121-32.

Lindsay, A.W. (1982). Institutional performance in higher education: The efficiency dimension. Review of Educational Research, 52, 175-99.

Malaysian Ministry of Higher Education (2007). The National Higher Education Strategic Plan Beyond 2020. Kuala Lumpur: Malaysian Government Press.

Malaysian Ministry of Higher Education (2009). Malaysia Higher Education Statistics, various years. Kuala Lumpur: Malaysian Government Press.

Meho, L.I. \& Rogers, Y. (2008). Citation counting, citation ranking and h-index of human-computer interaction researchers: A comparison of Scopus and Web of Science. Journal of the American Society for Information Science and Technology, 59, 1711-26.

Meho, L.I. \& Yang, K. (2007). Impact of data sources on citation counts and rankings of LIS faculty: Web of Science versus Scopus and Google Scholar. Journal of the American Society for Information Science and Technology, 58, 2105-25.

Meng, W., Zhang, D., Qi, L., \& Liu, W. (2008). Two level DEA approaches in research evaluation. Omega International Journal of Management Science, 36, 950-7.

Moorsteen, R.H. (1961). On measuring productive potential and relative efficiency. The Quarterly Journal of Economics, 75, 451-67.

Ng, Y.C. \& Li, S.K. (2000). Measuring the research performance of Chinese higher education institutions: An application of data envelopment analysis. Education Economics, 8, 139-56.

Norris, M. \& Oppenheim, C. (2007). Comparing alternatives to the Web of Science for coverage of the social sciences' literature. Journal of Informetrics, 1, 161-9.

O’Donnell, C.J. (2010a). Measuring and decomposing agricultural productivity and profitability change, Australian Journal of Agricultural and Resource Economics, 54, 527-60.

O’Donnell, C.J. (2010b). DPIN version 1.0: A program for decomposing productivity index numbers. Working paper WP01/2010. Queensland: Centre for Efficiency and Productivity Analysis.

O’Donnell, C.J. (2012a). An aggregate quantity framework for measuring and decomposing productivity change, Journal of Productivity Analysis, 38(3), 255-72.

O’Donnell, C.J. (2012b). Nonparametric estimates of the components of productivity and profitability change in U.S. agriculture, American Journal of Agricultural Economics, 94, 873-90.

Ray, S.C. \& Desli, E. (1997). Productivity growth, technical progress, and efficiency change in industrialized countries: Comment. The American Economic Review, 87, 1033-9.

Simões, P. \& Marques, R.C. (2012). Influence of regulation on the productivity of waste utilities:What can we learn with the Portuguese experience? Waste Management, 32, 1266-75.

Sinuany-Stern, Z., Mehrez, A. \& Barboy, A. (1994). Academic departments efficiency via DEA. Computers and Operations Research, 21, 543-56.

Tomkins, C. \& Green, R. (1988). An experiment in the use of data envelopement analysis for evaluating the efficiency of UK university departments of accounting. Financial Accountability and Management, 4, 147-65. 
Wheelock, D.C. \& Wilson, P.W. (1999). Technical progress, inefficiency, and productivity change in U.S. banking, 1984-1993. Journal of Money, Credit and Banking, 31, 212-34.

Worthington, A.C. \& Lee, B.L. (2008). Efficiency, technology and productivity change in Australian universities, 1998-2003. Economics of Education Review, 27, 285-98. 
Table 1 Input and output variables

\begin{tabular}{|c|c|c|}
\hline Variables & & Definition of variables \\
\hline \multicolumn{3}{|l|}{ Outputs } \\
\hline & $\begin{array}{l}\text { Undergraduate qualifications awarded } \\
\text { (Y1) }\end{array}$ & The total number of first degree qualifications awarded \\
\hline & $\begin{array}{l}\text { Postgraduate qualifications awarded } \\
\text { (Y2) }\end{array}$ & $\begin{array}{l}\text { The total number of postgraduate degree qualifications } \\
\text { awarded }\end{array}$ \\
\hline & Research output (Y3) & $\begin{array}{l}\text { The number of journal articles published in the Scopus } \\
\text { database }\end{array}$ \\
\hline \multicolumn{3}{|r|}{ me 50} \\
\hline & Undergraduate enrolments (X1) & The total number of first degree enrolments \\
\hline & Postgraduate enrolments (X2) & The total number of postgraduate student enrolments \\
\hline & Academic staff (X3) & $\begin{array}{l}\text { The number of full-time equivalent academic staff } \\
\text { members }\end{array}$ \\
\hline & Government research funding (X4) & $\begin{array}{l}\text { Funding provided by the government to support research } \\
\text { activities }\end{array}$ \\
\hline
\end{tabular}


Table 2 Descriptive statistics

\begin{tabular}{|c|c|c|c|c|c|c|c|c|}
\hline Year & Des. Statistics & $X 1$ & $X 2$ & $X 3$ & $X 4$ & $Y 1$ & $Y 2$ & $Y 3$ \\
\hline \multicolumn{9}{|l|}{2006} \\
\hline & Mean & $13,153.3$ & 2,299.9 & $1,222.3$ & $10,278,531.8$ & $3,246.6$ & 435.5 & 88.9 \\
\hline & Min & 2,413 & 37 & 292 & 100,021 & 84 & 1 & 0.2 \\
\hline & Max & 38,061 & 9,543 & 4,966 & $41,572,260$ & 9,403 & 1,493 & 349.6 \\
\hline & S.D. & $9,640.9$ & $2,801.3$ & $1,154.6$ & $12,736,402.8$ & $2,596.4$ & 481.7 & 133.9 \\
\hline & Sum & 223,606 & 39,099 & 20,779 & $174,735,041$ & 55,193 & 7,403 & 2,332 \\
\hline \multicolumn{9}{|l|}{2007} \\
\hline & Mean & $14,449.5$ & 2,426 & 1,359.3 & $18,129,365.7$ & $3,699.5$ & 541.2 & 107.4 \\
\hline & Min & 1,858 & 1 & 354 & 175,480 & 428 & 3.0 & 0.2 \\
\hline & Max & 47,746 & 7,635 & 6,001 & $95,902,406$ & 10,741 & 1,555 & 417.1 \\
\hline & S.D. & 11,812 & $2,422.9$ & 1,368.2 & $25,405,741.5$ & $2,735.9$ & 555.4 & 154.5 \\
\hline & Sum & 245,642 & 41,248 & 23,108 & $308,199,217$ & 6,2891 & 9,201 & 2,819 \\
\hline \multicolumn{9}{|l|}{2008} \\
\hline & Mean & $14,887.8$ & 2,740 & $1,438.7$ & $10,345,581.9$ & 3,358.6 & 580.6 & 156.3 \\
\hline & Min & $4,241.0$ & 111 & 412 & 616,400 & 214 & 1 & 0.3 \\
\hline & Max & 38,061 & 8,768 & 6,354 & $33,835,625$ & 9,403 & 1,479 & 632.4 \\
\hline & S.D. & $10,356.6$ & $2,915.8$ & $1,430.4$ & $12,196,161.9$ & $2,575.8$ & 553.9 & 232.2 \\
\hline & Sum & 253,092 & 46,582 & 24,458 & $175,874,893$ & 57,096 & 9,870 & 3,920 \\
\hline \multicolumn{9}{|l|}{2009} \\
\hline & Mean & $15,718.1$ & 3,478.6 & $1,531.5$ & $4,900,137.4$ & 3,861.1 & 559.5 & 242.7 \\
\hline & Min & 4,504 & 174 & 476 & 162,700 & 592 & 3 & 2.4 \\
\hline & Max & 57,486 & 8,532 & 7,270 & $22,623,647$ & 14,361 & 1,461 & $1,029.2$ \\
\hline & S.D. & $13,199.9$ & 3,362.1 & 1,622 & $6,292,148.1$ & 3,423 & 539.1 & 349.5 \\
\hline & Sum & 267,207 & 59,137 & 26,035 & $83,302,335$ & 65,639 & 9,511 & 6,276 \\
\hline
\end{tabular}


Table 3 Estimated mean output-oriented measures of technical, scale and mix efficiencies using the Hicks-Moorsteen method (2006-2009)

\begin{tabular}{|c|c|c|c|c|}
\hline Groups & Year & OTE & OSE & $O M E$ \\
\hline \multirow[t]{4}{*}{ Research universities } & 2006 & 0.9784 & 0.9986 & 0.9784 \\
\hline & 2007 & 1.0000 & 0.9823 & 0.9679 \\
\hline & 2008 & 1.0000 & 0.9766 & 0.9936 \\
\hline & 2009 & 0.9718 & 0.9944 & 0.9412 \\
\hline \multirow[t]{4}{*}{ Comprehensive Universities } & 2006 & 0.9496 & 0.9925 & 0.9486 \\
\hline & 2007 & 0.9390 & 0.9836 & 0.7521 \\
\hline & 2008 & 1.0000 & 0.9863 & 0.9222 \\
\hline & 2009 & 0.9558 & 0.9399 & 0.8886 \\
\hline \multirow[t]{4}{*}{ Focused universities } & 2006 & 1.0000 & 0.8990 & 0.8939 \\
\hline & 2007 & 0.9292 & 0.9889 & 0.9066 \\
\hline & 2008 & 0.9979 & 0.8735 & 0.9971 \\
\hline & 2009 & 1.0000 & 0.9694 & 1.0000 \\
\hline \multirow[t]{4}{*}{ The sector } & 2006 & 0.9759 & 0.9634 & 0.9403 \\
\hline & 2007 & 0.9561 & 0.9849 & 0.8755 \\
\hline & 2008 & 0.9993 & 0.9455 & 0.9709 \\
\hline & 2009 & 0.9760 & 0.9679 & 0.9433 \\
\hline
\end{tabular}

Note: OTE = output-oriented technical efficiency; OSE = output-oriented scale efficiency; OME = outputoriented mix efficiency. 
Table 4 TFP changes and its components for different university sub-grouping between 2006 and 2009

\begin{tabular}{|c|c|c|c|c|c|c|c|}
\hline Groups & Period & $\triangle T F P$ & $\Delta T e c h$ & $\Delta E f f$ & $\triangle O T E$ & $\triangle R O S E$ & $\triangle O M E$ \\
\hline \multirow[t]{3}{*}{$\begin{array}{l}\text { Research } \\
\text { universities }\end{array}$} & 2006-2007 & 0.9793 & 3.2118 & 0.3049 & 1.0228 & 0.9897 & 0.3012 \\
\hline & 2007-2008 & 1.2026 & 0.3188 & 3.7723 & 1.0000 & 1.0271 & 3.6729 \\
\hline & 2008-2009 & 1.7212 & 1.1167 & 1.5413 & 0.9718 & 0.9476 & 1.6738 \\
\hline \multirow[t]{3}{*}{$\begin{array}{l}\text { Comprehensive } \\
\text { universities }\end{array}$} & 2006-2007 & 0.9817 & 3.2118 & 0.3057 & 1.0021 & 0.7784 & 0.3919 \\
\hline & 2007-2008 & 1.2177 & 0.3188 & 3.8198 & 1.0704 & 1.3938 & 2.5603 \\
\hline & 2008-2009 & 1.2050 & 1.1167 & 1.0790 & 0.9558 & 0.9605 & 1.1755 \\
\hline \multirow[t]{3}{*}{$\begin{array}{l}\text { Focused } \\
\text { universities }\end{array}$} & 2006-2007 & 2.3048 & 3.2118 & 0.7176 & 0.9292 & 1.4715 & 0.5249 \\
\hline & 2007-2008 & 1.3392 & 0.3188 & 4.2009 & 1.1613 & 1.3522 & 2.6754 \\
\hline & 2008-2009 & 1.9617 & 1.1167 & 1.7567 & 1.0021 & 1.0030 & 1.7478 \\
\hline \multicolumn{8}{|l|}{ The sector } \\
\hline & 2006-2007 & 1.3865 & 3.2118 & 0.4317 & 0.9847 & 1.0799 & 0.4060 \\
\hline & 2007-2008 & 1.2826 & 0.3188 & 4.0231 & 1.0772 & 1.2577 & 2.9695 \\
\hline & 2008-2009 & 1.6215 & 1.1167 & 1.4520 & 0.9766 & 0.9703 & 1.5323 \\
\hline
\end{tabular}

Note: $\triangle T F P=\Delta T e c h \times \Delta E f f$ and $\triangle E f f=\triangle O T E \times \triangle R O S E \times \triangle O M E$. 


\section{Notes}

${ }^{1}$ Gilbert and Wilson (1998), Glass and McKillop (2000) and Arjomandi et al. (2011) experienced this difficulty in their studies of the Korean banks, UK building societies, and Iranian banks, respectively.

${ }^{2}$ Briec and Kerstens (2004) also proposed an interesting difference-based variation of the Malmquist index known as the Luenberger-Hicks-Moorsteen indicator in the literature. For more recent theoretical contributions on the Hicks-Moorsteen index see also Briec and Kerstens (2011), Briec et al. (2012), and Kerstens and Van de Woestyne (2014).

${ }^{3}$ Research universities are well-established, research-intensive institutions. According to Malaysian Ministry of Higher Education (2007), this category is awarded to universities that place emphasis on aspects of research and development. These universities share the following features: (a) research-oriented subject areas; (b) competitive entry requirement; (c) highly-qualified academics. Comprehensive universities (also called multi-disciplinary universities) focus on a wide range of courses and fields of specialization. The four common characteristics among these universities are: (a) wide range of subject areas; (b) competitive entry requirement; (c) highly-qualified academics. Focused universities focus on certain fields of knowledge related to the original objective of their establishment. They have the same characteristics as research universities.

${ }^{4}$ All research is on the focused and established institutions: Universiti Malaya, Universiti Sains Malaysia, Universiti Kebangsaan Malaysia, Universiti Putra Malaysia, and Universiti Teknologi Malaysia.

${ }^{5}$ Also called multi-disciplinary universities, which focus on a wide cross-section of courses and fields of study: Universiti Islam Antarabangsa Malaysia, Universiti Malaysia Sarawak, Universiti Malaysia Sabah, and Universiti Teknologi MARA.

${ }^{6}$ They concentrate on specified disciplines linked to the original objective of their establishment: Universiti Utara Malaysia, Universiti Pendidikan Sultan Idris, Universiti Malaysia Terengganu, Universiti Sains Islam Malaysia, Universiti Tun Hussein Onn, Universiti Teknikal Melaka Malaysia, Universiti Malaysia Pahang, and Universiti Malaysia Perlis.

${ }^{7}$ Peer-review approach is an evaluation process of research output carried out by qualified individuals within the relevant areas. This approach was adopted by Johnes (1995) and Meng et al. (2008).

${ }^{8}$ This is entirely consistent with the theory behind technical changes explained by O'Donnell (2012a). 